\title{
Larra Wasps, Larra analis Fabricius; Mole Cricket Hunters, Larra bicolor Fabricius (suggested common names) (Insecta: Hymenoptera: Sphecidae) ${ }^{1}$
}

\section{J. H. Frank and A. Sourakov ${ }^{2}$}

\section{Introduction}

Wasps of the genus Larra (Hymenoptera: Sphecidae) have a worldwide distribution in the tropics; few exist in temperate regions. They are solitary wasps, have no communal nests to guard, and are not "aggressive." All of them are parasitoids, and all, so far as is known, attack only mole crickets (Orthoptera: Gryllotalpidae) but, to each Larra species, not all mole cricket species are acceptable hosts (Bohart and Menke 1978, Menke 1992).

\section{Distribution}

Two species of Larra now occur in Florida. Larra analis Fabricius is a native species, widely distributed in the eastern USA, at least as far north as Pennsylvania and as far west as Kansas, in places where its host, the native mole cricket Neocurtilla hexadactyla (Perty), is distributed.

Larra bicolor is native to South America, where it is widespread. The story of its introduction to Florida is given below. The population that now

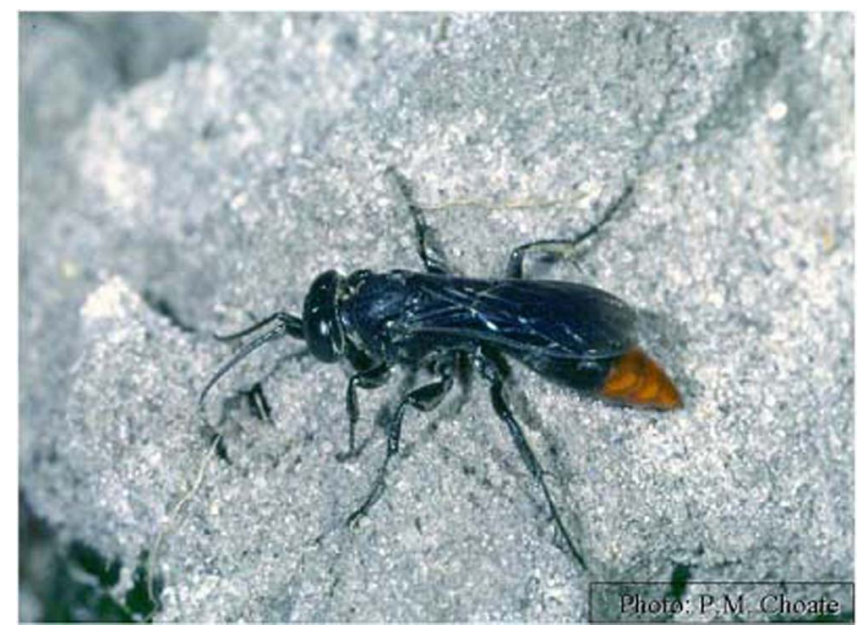

Figure 1. Adult Larra analis Fabricius, a parasitoid of the northern mole cricket, Neocurtilla hexadactyla (Perty).

Credits: P.M. Choate, University of Florida

exists in the Ft. Lauderdale area originated from Belém, Brazil (by way of Puerto Rico). The population that exists in some counties of northern Florida originated from Bolivia. Adults of these two populations can be distinguished by microsculpture of the head. The microsculpture patterns are illustrated in scanning electron micrographs provided

1. This document is EENY-268, one of a series of Featured Creatures from the Entomology and Nematology Department, Florida Cooperative Extension Service, Institute of Food and Agricultural Sciences, University of Florida. Published: March 2002. This document is also available on Featured Creatures Website at http://creatures.ifas.ufl.edu. Please visit the EDIS Website at http://edis.ifas.ufl.edu. Additional information on these organisms, including many color photographs, is available at the Entomology and Nematology Department website site at http://entnemdept.ifas.ufl.edu/.

2. J. H. Frank, professor, Entomology and Nematology Department, University of Florida, Institute of Food and Agricultural Sciences, Gainesville, FL 32611 and A. Sourakov, CMAVE-ARS-USDA, Gainesville, FL.

The Institute of Food and Agricultural Sciences (IFAS) is an Equal Employment Opportunity - Affirmative Action Employer authorized to provide research, educational information and other services only to individuals and institutions that function without regard to race, creed, color, religion, age, disability, sex, sexual orientation, marital status, national origin, political opinions or affiliations. For information on obtaining other extension publications, contact your county Cooperative Extension Service office. Florida Cooperative Extension Service / Institute of Food and Agricultural Sciences / University of Florida / Larry R. Arrington, Interim Dean 
by Menke (1992). Its hosts are the pest Scapteriscus mole crickets whose origin, likewise, is South America. Three species of Scapteriscus - S. abbreviatus Scudder, S. borellii Giglio-Tos, and $S$. vicinus Scudder occur in Florida, and all are attacked by L. bicolor.

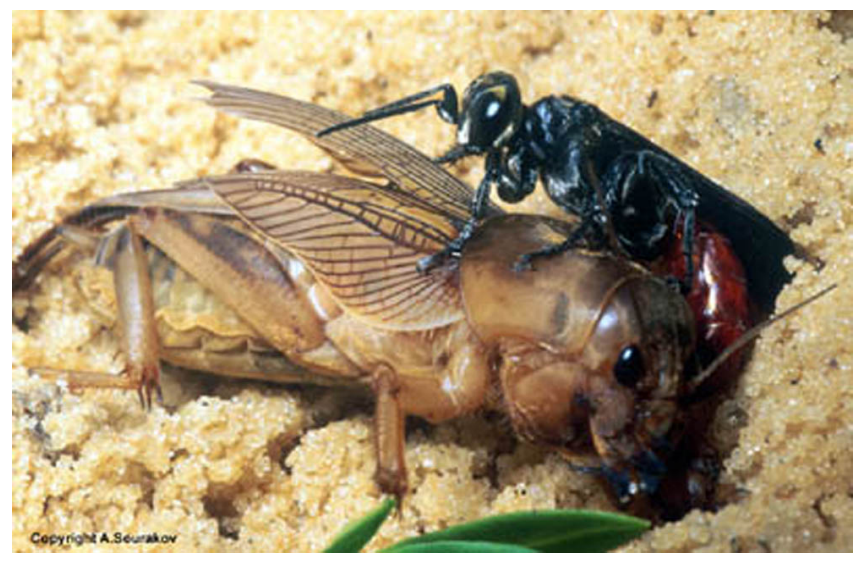

Figure 2. An adult Larra bicolor Fabricius preparing to oviposit on a mole cricket. Credits: A. Sourakov, USDA

\section{Description}

Black wasps in which the abdomen is partially (L. analis) or totally (L. bicolor) red, with silvery white markings on the head. Wings smoky brown to indigo blue. In both sexes: claws short and without inner teeth; foretibia with spine rows; without teeth on inner margin of mandible; propodeum constricted at level of spiracles; integument glossy. In females additionally: pronotal collar thick, straight on top and as high as scutum; sternum II without a pair of special flattened oval areas basally; pygidial plate bare and without a transverse row of short setae apically. Length of females of $L$. analis and L. bicolor up to about $22 \mathrm{~mm}$; males smaller.

\section{Life Cycle}

In the southern USA, adult wasps (both species) have been seen as early as May and as late as December, with a longer activity period in southern Florida. They have been seen most abundantly in the autumn (September to November), usually feeding at flowers. These flowers include Chamaecrista fasciculata (Michx.) Greene [partridge pea] and Vigna unguiculata (L.) Walp. [cowpea] (Fabaceae), Solidago [goldenrod] and Eupatorium [boneset] (Asteraceae), Pimpinella anisum (1.) [anise]
(Apiaceae, formerly Umbelliferae), Hyptis atrorubens (Poit.) (Lamiaceae), Spermacoce verticillata $\mathrm{L}$. [shrubby false buttonweed] (Rubiaceae), Poinsettia heterophylla (L.) [fiddler's spurge] (Euphorbiaceae) and others. The diversity of plants suggests that the need of these wasps is not for plants of a particular family, but for shallow flowers from which they can obtain nectar. Most wasps seen feeding are males perhaps because females spend time hunting mole crickets.

Apart from attraction to flowers, wasps are attracted to the chemical phenylacetaldehyde (Meagher and Frank 1998).

When they are not feeding at flowers, wasps are seldom seen. A lucky or patient observer may see a female wasp running on the ground stopping and running again, during the brightest hours of the day. With luck, the observer will see the female wasp enter a gallery (= horizontal burrow) made by a mole cricket. Shortly thereafter, a mole cricket may be seen emerging from the ground, with the wasp in pursuit. She will pounce on it, wrestle with it, and sting it on its soft underside, thus immobilizing it for a few minutes. As the mole cricket lies inert on the ground, the wasp lays a single egg on its underside. The oviposition may easily be staged in a laboratory, by inserting a mole cricket into a glass or plastic vial containing a female wasp. She wastes little time in attacking it. Female L. analis oviposit behind a hind leg of the host (Smith 1935) whereas female $L$. bicolor oviposit between the first and second pairs of legs of the host (Castner 1988b).

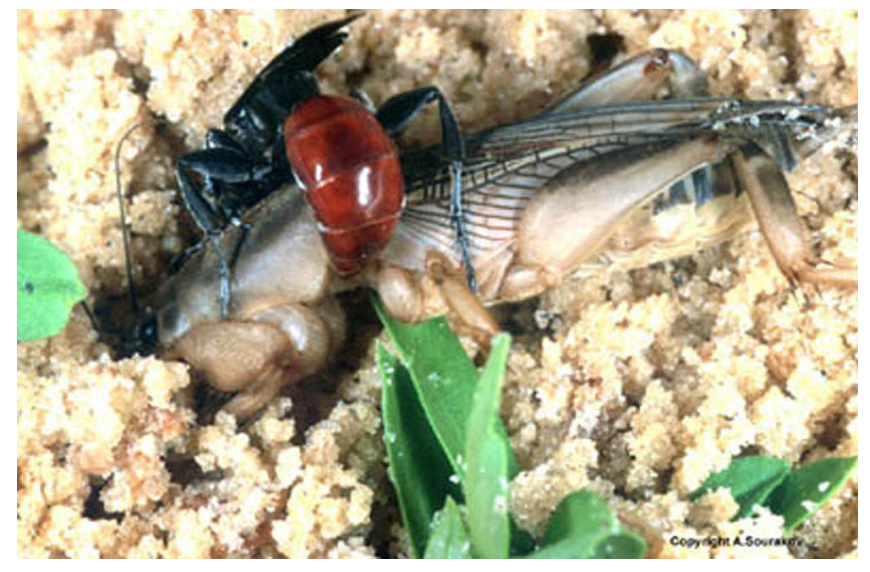

Figure 3. An adult Larra bicolor Fabricius preparing to sting a mole cricket it has chased from a gallery excavated by the mole cricket. Credits: A. Sourakov, USDA 


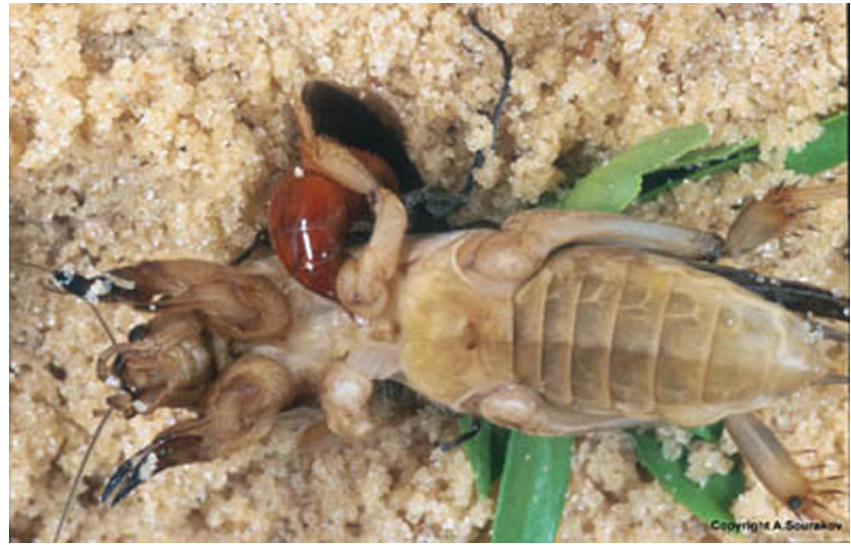

Figure 4. An adult Larra bicolor Fabricius stinging a mole cricket. Credits: A. Sourakov, USDA

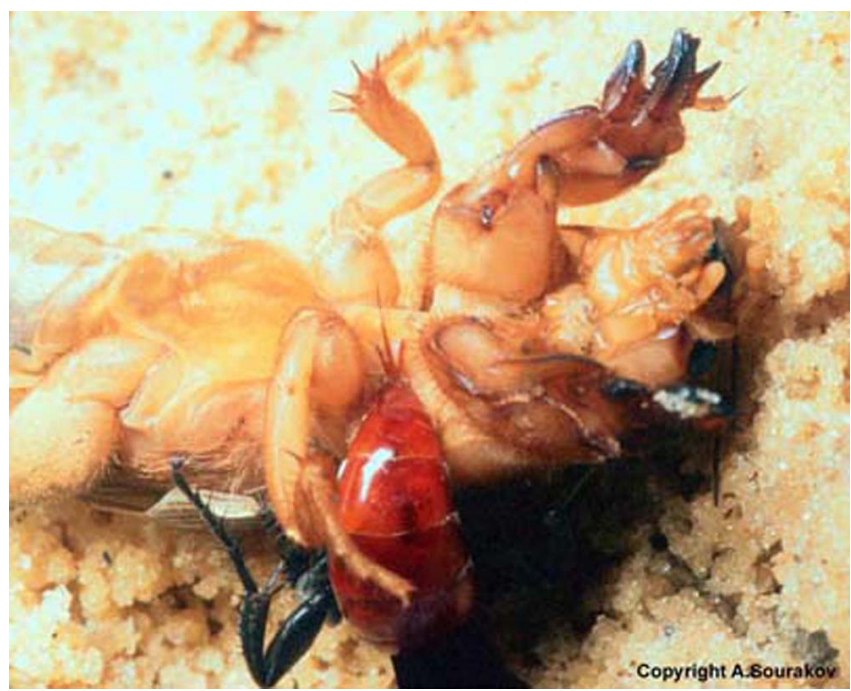

Figure 5. The ovipositor of an adult Larra bicolor Fabricius is plainly seen as the wasp lays an egg while the mole cricket is paralyzed. Credits: A. Sourakov, USDA

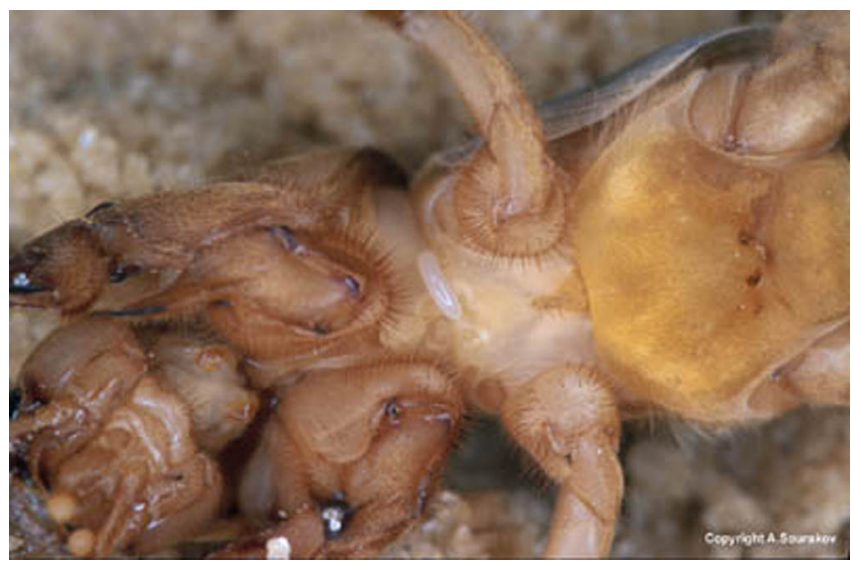

Figure 6. An egg of the wasp parasitoid Larra bicolor Fabricius deposited on the ventral side of the thorax of a mole cricket. The elongate, pearly white egg is central in the picture. Credits: A. Sourakov, USDA
After the mole cricket is paralyzed, the female wasp may imbibe a little hemolymph from it before she oviposits, in a process called "host-feeding." The purpose of "host-feeding" is obscure.

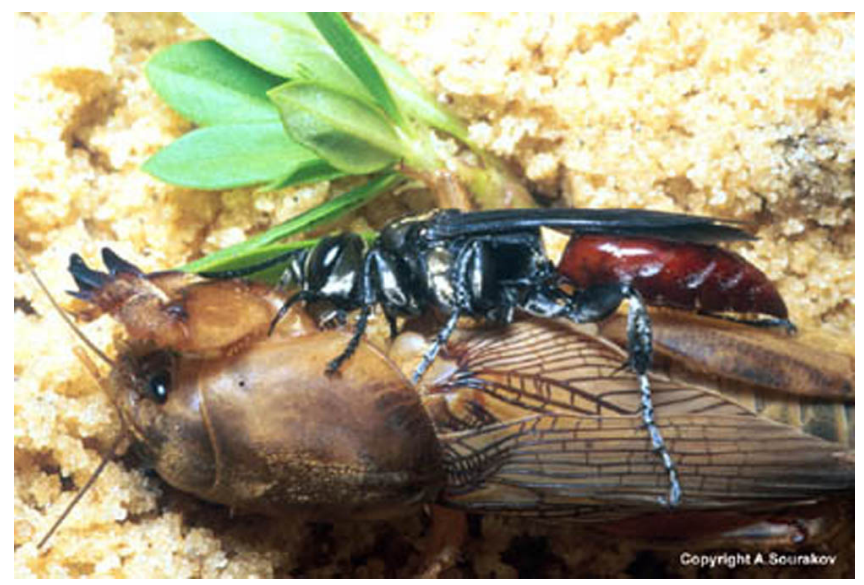

Figure 7. An adult Larra bicolor Fabricius feeding on a mole cricket by imbibing hemolymph. Credits: A. Sourakov, USDA

Once an egg has been laid, the wasp leaves the mole cricket. The latter soon recovers from its temporary paralysis and burrows back into the ground.

The venom of female Larra wasps seems designed to cause only temporary paralysis of the host, in contrast to the sting of closely related wasps in the genus Liris, which attack crickets (but not mole crickets) and whose host does not resume its full repertoire of behavior (Steiner 1984). Yet other sphecid wasps paralyze their prey permanently, drag the prey items into to cells that they have dug in the ground, and there lay eggs on them. Larra is thus exceptional among sphecid wasps, which are commonly called "digger wasps" because females of these other genera dig cells in which to deposit their paralyzed hosts. Larra females are "digger wasps" that do not dig.

Mole cricket nymphs that are less than about a third to half grown are not attacked by the wasps. Otherwise, the wasps seem to show no preference for size of host.

Incubation time of the eggs is temperaturedependent and may be as rapid as four days in summer. Total development time from oviposition to pupation is also temperature-dependent, and ranges 
from a minimum of about 12 days to a maximum of about 30 days (Smith 1935). Wasp larvae develop as ectoparasitoids, with mandibles inserted into the host. The larvae have five instars (Cushman 1935).

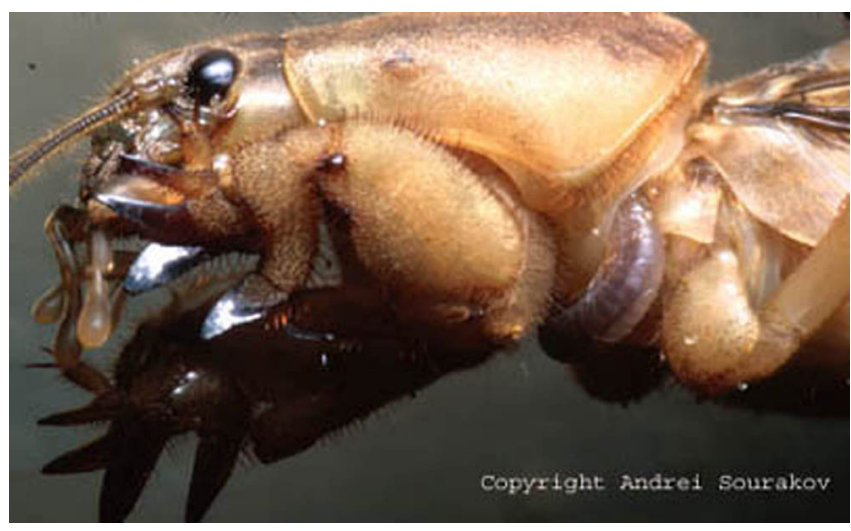

Figure 8. A developing larva of Larra bicolor Fabricius feeding on a mole cricket. The larva is a little to the right of the center of the picture. Credits: A. Sourakov, USDA

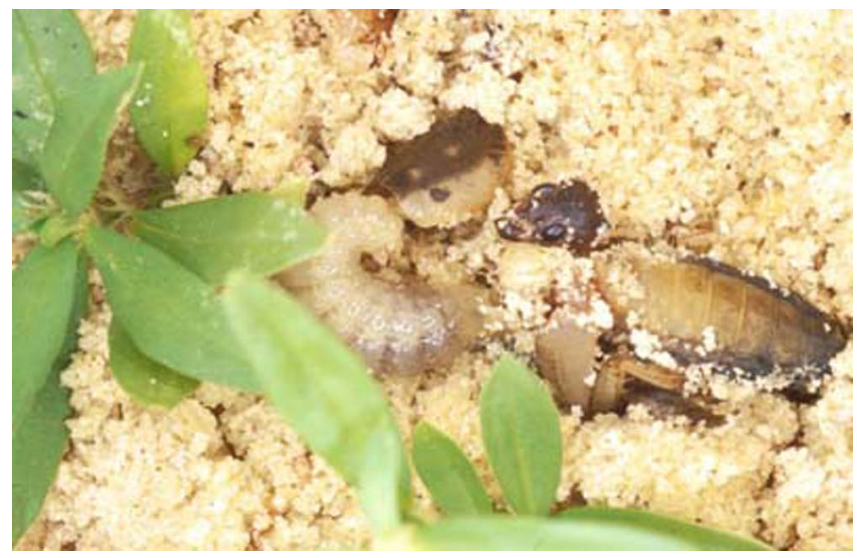

Figure 9. A fully grown larva of Larra bicolor Fabricius near pieces of the mole cricket on which it developed. Credits:

A. Sourakov, USDA

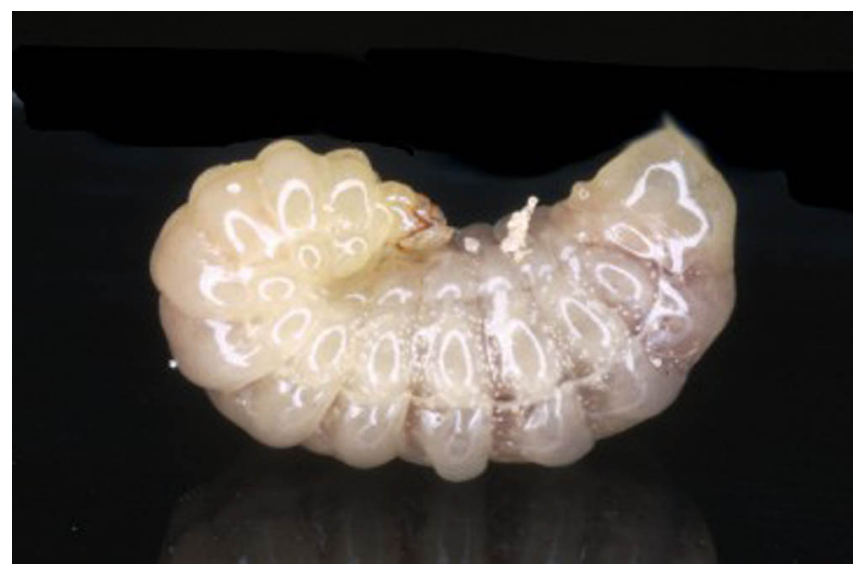

Figure 10. A fully grown larva of Larra bicolor Fabricius. Credits: A. Sourakov, USDA
The fully-grown wasp larva pupates among the remains of the dead host, or close to it, in the ground. A cocoon is formed by cementing sand grains or other particles together. The duration of the pupal stage is highly variable, ranging from a little less than 50 days in summer to many months during the winter, in diapause. It is not yet known what initiates or ends this diapause. In the vicinity of Baton Rouge, Louisiana, L. analis undergoes at least three generations during the summer and autumn, but winter causes above-ground activity to cease. The situation is the same with L. bicolor in northern Florida. In effect, adult wasps are present continuously during the autumn months, and generations are not discrete. Adult wasps have been found dead on the ground after the first night of the winter that has below-freezing temperatures.

\section{Introduction of $L$. bicolor into Florida}

Scapteriscus mole crickets arrived in the southeastern USA about 1900. They are strongly believed to have arrived as stowaways in ships' ballast thus as immigrants, not as introduced species (here we reserve the word "introduced" for those species that were introduced deliberately). As their populations increased and spread, they became important pests of cultivated crops, turf grasses, and pasture grasses. Although they became abundant, the native wasp Larra analis did not adapt to attack them, and attacked only its original host, the native mole cricket Neocurtilla hexadactyla. Although Neocurtilla and Scapteriscus belong to the same family (Gryllotalpidae: mole crickets), they are only distantly related to one another. It is important to realize that there are more than 80 species of mole crickets worldwide, that they have a long evolutionary history over at least tens of millions of years, and that the genus Scapteriscus evolved in South America. In contrast, the genus Neocurtilla seems to have evolved in North America. Newspaper reports about "the mole cricket" (as if only one species of mole cricket exists!) oversimplify the situation to the point where such reports are misleading.

In 1938, Larra bicolor was introduced successfully into Puerto Rico from Amazonian Brazil as a biological control agent of Scapteriscus 
didactylus (Latreille). This mole cricket, whose common name in Puerto Rico is la changa (sometimes called West Indian mole cricket) was an important pest (Wolcott 1938). Despite confused accounts in the entomological literature, this mole cricket species does not occur in mainland USA.

The importance of Scapteriscus mole crickets as pests in Florida, and news of the successful introduction of Larra bicolor into Puerto Rico as a biological control agent, led to attempts to introduce L. bicolor into Florida. The first attempts were made in the 1940s. The attempts were unsuccessful, and were abandoned when the efficacy of chlordane was discovered as a pesticide for controlling pest mole crickets (Frank 1990). Thirty years of use of chlordane followed, with mole crickets as targets in plantings of vegetables, turf grass, and pasture grasses.

When chlordane was banned by the US Environmental Protection Agency, the Florida Legislature ordered in 1978 that a mole cricket research program be initiated by the University of Florida's Institute of Food and Agricultural Sciences (UF/IFAS). This led to renewed attempts to import Larra bicolor and other biological control agents for pest mole crickets, using earmarked State funds. Because of administrative rules that barred use of such funds for foreign travel, for example to search for biological control agents in the South American homelands of Scapteriscus mole crickets, one option was to import Larra bicolor from Puerto Rico (a US commonwealth, not a foreign country).

Beginning in 1979, UF/IFAS researchers visited Puerto Rico in an attempt to collect living Larra bicolor and bring them to Florida. Researchers involved were R.I. Sailer, J.A. Reinert, W.G. Hudson, J.L. Castner, and H.G. Fowler. Adult wasps were collected in Puerto Rico and were released in Florida at sites where Spermacoce verticillata had been planted as a nectar source to support their existence. Releases were made in Gainesville, Tampa, Lakeland, Bradenton, and Ft. Lauderdale (Frank 1990, Sailer 1985). This was done with the required USDA-APHIS federal permits. A special dispensation was allowed by USDA-APHIS: most such permits require the biological control agent to be reared for at least a generation in a quarantine facility to obviate contamination of biocontrol agents by hyperparasitoids. Because of the difficulty of rearing L. bicolor in the laboratory, it was permitted that the adult wasps be imported and released directly, without a generation in quarantine.

Only wasps released at Ft. Lauderdale established a population. At the four other sites, releases were unsuccessful. The Ft. Lauderdale population dates to 1981 importations. By 1987 it seemed to exist only at the UF/IFAS Ft. Lauderdale Research and Education Center, having failed to survive at a nearby golf course (the golf course management inadvertently destroyed the Spermacoce plants and applied methyl bromide). Subsequent research by J.L. Castner (a) revealed details of its behavior, (b) failed to distribute it to additional localities, (c) documented a parasitism level of $<1 \%$ on the mole cricket Scapteriscus abbreviatus (and none on S. borellii or S. vicinus), and (d) showed experimentally that overwintering survival of wasp pupae at Gainesville was much less than at Ft. Lauderdale (Castner 1988a). These findings did not show the "Puerto Rican" strain (originally from Belém, PA, Brazil) of the wasp to be of much value in controlling pest mole crickets in southern Florida, and suggested that winters in northern Florida were disastrous for it.

UF/IFAS researcher F.D. Bennett saw J.L. Castner's findings as a suggestion that Larra bicolor wasps from cooler climates in South America might be better adapted to survival in Florida. With funds (from the UF/IFAS mole cricket research program) and support from Bolivian resident C.J. Pruett, he investigated behavior of L. bicolor at Santa Cruz, Bolivia (Bennett and Pruett 1991, Pruett and Bennett 1991). Then, in 1988 and 1989 he imported living adult $L$. bicolor wasps from Bolivia for direct release into Florida. Again, USDA-APHIS permitted this direct importation. Female wasps were exposed in quarantine to Florida-grown Scapteriscus mole crickets; these mole crickets, parasitized by Larra eggs, were released in the field by F.D. Bennett, J.H. Frank, and J.P. Parkman. The female wasps, after they had parasitized many mole crickets in quarantine, were likewise released in the field. All imported adult wasps, before release in Florida, were 
examined microscopically for presence of rhipiphorid larvae: such beetle larvae are reported as parasitoids of Larra, and would be expected to harm and reduce the effectiveness of the wasps; no rhipiphorid larvae were detected. Three release sites were employed, all in the Gainesville area.

In the autumn of 1993, the Bolivian stock of $L$. bicolor was found to have established a population in the Gainesville area (Frank et al. 1995). Subsequent observations over the next several years showed that the population had spread to several neighboring counties (not yet published). Evaluation by two graduate students (L. Treadwell, H. Cabrera, not yet published) showed the high level of effectiveness of L. bicolor as a biological control agent of Scapteriscus mole crickets at two sites in the Gainesville area.

It is expected that $L$. bicolor will eventually spread its populations through most of Florida. However, such is its measured effectiveness as a biological control agent that deliberate attempts to hasten its colonization of the rest of Florida are worthwhile. Toward this objective, plans are now being developed (March 2002) to distribute stock to other regions of Florida that yet have no L. bicolor population.

\section{Nontarget Species}

Larra wasps attack mole crickets only (Bohart and Menke 1978, Menke 1992). Nevertheless, questions about the ability of L. bicolor to attack the native mole cricket Neocurtilla hexadactyla arose. This native mole cricket was not a target of the biological control effort in Florida. It was shown that L. bicolor wasps were unsuccessful in $90 \%$ of attempts to parasitize $N$. hexadactyla because the latter defends itself by discharging a sticky secretion that entangles the wasp (Castner 1984). It was later shown that even when a wasp successfully lays an egg on $N$. hexadactyla, the egg dies, or the wasp larva that hatches from the egg dies (Pruett and Bennett 1991). Thus, native mole crickets do not seem to be at risk.

In answer to the question "What if L. bicolor evolves to overcome the defenses of $N$. hexadactyla?" we have two responses. First, nobody can be sure what direction future evolution will take in any wild organism. Second, a 100-year inadvertent experiment already has taken place. The native wasp Larra analis has not evolved to attack Scapteriscus mole crickets in the 100 years during which it has been exposed to them even though they must surely represent a substantial food source because they are abundant. So, what would be the evolutionary advantage for the introduced wasp to adapt to attack the native mole cricket, which is a relatively rare food resource?

\section{Nectar Sources}

It has been observed for many decades that adult Larra wasps visit wildflowers to obtain nectar. The number of wildflower species reported as nectar sources for Larra is short. It may be that provision of patches of these wildflowers can enhance the numbers of Larra wasps that can persist in any area. This could improve biological control of Scapteriscus mole crickets. Spermacoce verticillata is one of these plants. Its status as a native plant is unclear, but it is widespread in many counties in southern Florida, and it seems to provide nectar throughout the year. In northern Florida it freezes to the ground at the first winter frost, but provides nectar from May until then. Patches of $S$. verticillata, planted in northern Florida, are now used as study sites for the wasps, and as places where the wasps may be harvested for shipment to other regions. The effect of such patches of $S$. verticillata on Larra populations is now under investigation, and their use is now viewed as being akin to "butterfly farming." Other species of wildflowers useful to Larra wasps are being sought (Frank and Parkman 1999).

\section{Selected References}

Bennett FD, Pruett CJ. 1991. Observations on copulation in Florida and on the behavior of male and female wasps of the genus Larra in Santa Cruz, Bolivia. Sphecos 21: 16-17.

Bohart RM, Menke AS. 1976. Sphecid wasps of the world. A generic revision. Univ California Press, Berkeley.

Castner JL. 1984. Suitability of Scapteriscus spp. mole crickets as hosts of Larra bicolor (Hymenoptera: Sphecidae). Entomophaga 29: 323-329. 


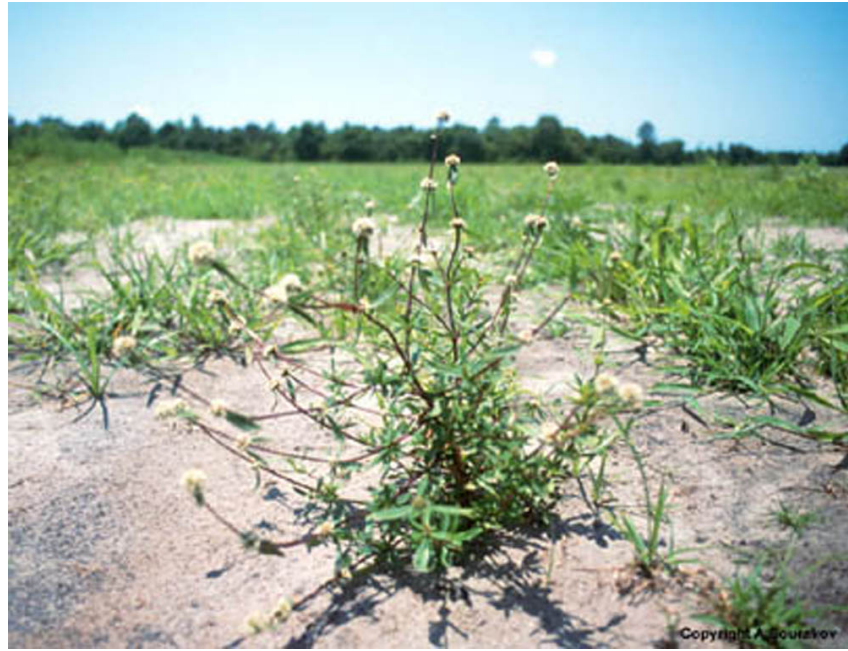

Figure 11. Spermacoce verticillata, a wildflower that provides a nectar source for adult Larra wasps. Credits: A. Sourakov, USDA

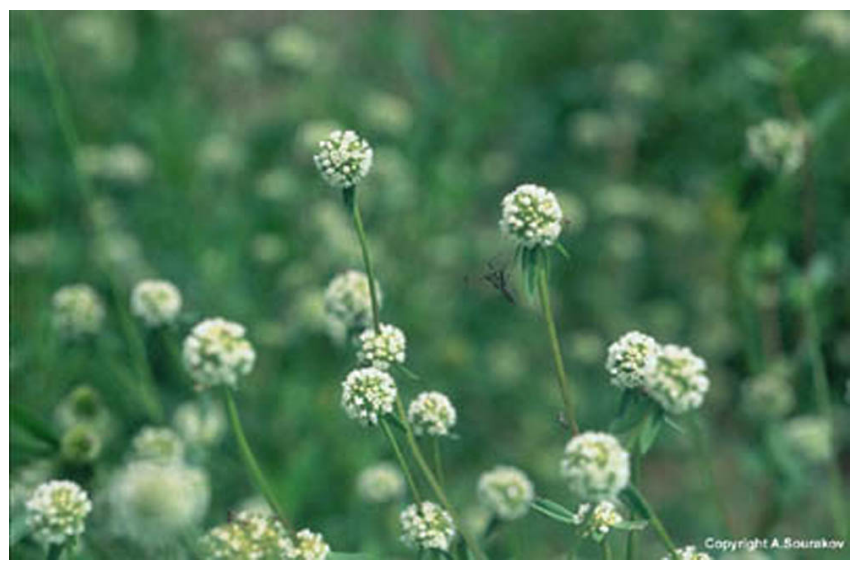

Figure 12. Inflorescences of Spermacoce verticillata, a wildflower that provides a nectar source for adult Larra wasps, have tiny white flowers. One of the "common" names of this wildflower is shrubby false buttonweed. We prefer to call it southern Larraflower. We hope that a native species of Spermacoce in northern Florida can be developed as "northern Larraflower." Credits: A. Sourakov, USDA

Castner JL. 1988a. Evaluation of Larra bicolor as a biological control agent of mole crickets. $\mathrm{PhD}$ Dissertation, Univ Florida.

Castner JL. 1988b. Biology of the mole cricket parasitoid Larra bicolor (Hymenoptera: Sphecidae), pp. 131-139 in Gupta VK (ed.) Advances in parasitic Hymenoptera research. Brill; Leiden.

Cushman RA. 1935. A study of the larva of Larra analis Fabricius. Proceedings of the Entomological Society of Washington 37: 82-87.
Frank JH. 1990. Mole crickets and other arthropod pests of turf and pastures, pp. 131-139 in Habeck DH, Bennett FD, Frank JH (eds.) Classical biological control in the southern United States. Southern Cooperative Series Bulletin 355: i-viii, 1-197.

Frank JH, Fasulo TR, Short DE. (2002). MCricket: Alternative Methods of Mole Cricket Control. http://molecrickets.ifas.ufl.edu/ (24 February 2002).

Frank JH, Parkman JP. 1999. Integrated pest management of pest mole crickets with emphasis on the southeastern USA. Integrated Pest Management Reviews 4: 39-52.

Frank JH, Parkman JP, Bennett FD. 1995. Larra bicolor (Hymenoptera: Sphecidae), a biological control agent of Scapteriscus mole crickets (Orthoptera: Gryllotalpidae), established in northern Florida. Florida Entomologist 78: 619-623.

\section{Meagher RL, Frank JH. 1998. Larra bicolor} (Hymenoptera: Sphecidae: Larrinae) collected in pheromone- and phenylacetaldehyde-baited traps. Florida Entomologist 81: 555-556.

Menke AS. 1992. Mole cricket hunters of the genus Larra in the New World (Hymenoptera: Sphecidae; Larrinae). Journal of Hymenoptera Research 1: 175-234.

Pruett CJ, Bennett FD. 1991. Behavior of two species of Larra in Santa Cruz, Bolivia. Sphecos 21: $15-16$.

Sailer RI. 1985. Natural enemies, pp. 23-32 in Walker TJ (ed.) Mole crickets in Florida. Florida Agricultural Experiment Stations Bulletin 846 (1984), 54 pp.

Smith CE. 1935. Larra analis Fabricius, a parasite of the mole cricket Gryllotalpa hexadactyla Perty. Proceedings of the Entomological Society of Washington 37: 65-82. [NOTE: this mole cricket is now called Neocurtilla hexadactyla, and is not viewed as belonging to the genus Gryllotalpa].

Steiner AL. 1984. Why can mole crickets stung by Larra wasps (Hymenoptera, Sphecidae: Larrinae) 
resume normal activities? The evolution of temporary paralysis and permanent deactivation of the prey. Journal of the Kansas Entomological Society 57: 152-154.

Wolcott GN. 1938. The introduction into Puerto Rico of Larra americana Saussure, a specific parasite of the "changa" or Puerto Rican mole cricket,

Scapteriscus vicinus. Journal of Agriculture of the University of Puerto Rico 22: 193-218. [NOTE: in reality, the wasp is Larra bicolor and the mole cricket is Scapteriscus didactylus]. 